\title{
ESSAY \\ Ecology: an integrated science for the artificialization of nature
}

\author{
Juan Gastó1, Diego Subercaseaux ${ }^{2}$, and Leonardo Vera ${ }^{3,4}$ \\ ${ }^{1}$ Departamento de Ciencias Animales. ${ }^{2}$ Laboratorio de Ecosistemas. Facultad de Agronomía e Ingeniería \\ Forestal. Pontificia Universidad Católica de Chile. Ave. Vicuña Mackenna 4860. Santiago, Chile. \\ ${ }^{3}$ Facultad de Agronomía, Pontificia Universidad Católica de Valparaíso. Casilla 4-D, Quillota, Chile. \\ ${ }^{4}$ Centro Regional de Innovación Hortofrutícola de Valparaíso, CERES. Casilla 4-D, Quillota, Chile.
}

\begin{abstract}
J. Gastó, D. Subercaseaux, and L. Vera. 2012. Ecology: an integrated science for the artificialization of nature. Cien. Inv. Agr. 39(3): 397-410. The main challenges confronting contemporary agronomy are being addressed according to the emerging and complex problems of our era. Agronomy corresponds to the science and profession of solving the problems of agriculture. The emergence of agronomy in sociocultural processes and their coevolution is described, as agronomy represents the determinant for the artificialization of nature, the management of natural resources and the transformation and management of land. The integration of nature, culture and human well-being inform the tendencies that are expressed in the cultural landscape. Ecology, ecosystem, territory and cultural landscape are the resultant aspects that provide the basis for the study and development of natural resource and ecosystem management. These subjects also allow us to understand the transition from nature to natural resources. All of these issues are associated with the transition of agronomy from a Cartesian analytical science to an integrative, systemic science, leading to a holistic and transdisciplinary paradigm that must be applied to the agronomic profession and to rural engineering. To be applicable to the problems of our era, the modern agronomic paradigm must be holistic and transdisciplinary and must cross the four hierarchical levels of the sciences: valoric, normative, pragmatic and empirical. This paradigm must also adapt to the unique conditions of various regions and to the evolution of the processes that are characteristic of complex systems associated with the construction of a rurality that is propitious for sustainability and quality of life.
\end{abstract}

Key words: Agronomy, cultural landscape, ecology, ecosystem, evolution of agronomy, natural resources, sociocultural processes, territory, transdisciplinarity.

\section{Introduction}

Many years ago, a former Rector of the Universidad de Chile (the philosopher and Professor Juan Gómez Millas) described an event that he had experienced, which he considered signifi-

Received September 28, 2011. Accepted May 16, 2012. Corresponding author: jgasto@uc.cl cant. To gather useful information for arguments regarding the restructuring of the Faculty of Agronomy, he and other professors and agronomy engineers visited several universities and the rural landscape on the Iberian Peninsula. During the trip, the group observed a farmer on open land, placing his hand into a rucksack, grabbing a fistful of seeds and throwing them into the air. Meanwhile, he said: "for God, for birds, for my family," and performed this action repeatedly. 
According to Rector Millas' interpretation, the farmer completely understood the meaning of agriculture; he integrated its three fundamental components. The first component incorporates permanent values that are related to agriculture and rural life. The second component indicates that nothing is free in nature, which refers to the second law of thermodynamics; if we want do agriculture, some seeds must be for the wild organisms, integrating nature, fauna, flora and soil. The third component is family, who are the social stakeholders participating in the process.

The world is changing gradually but deeply. Therefore, that farmer, now an entrepreneur, would currently be saying: for the bank, for taxes, for the inputs. He would move to a distant city, leaving the country uninhabited.

Localizing problems: challenges for agronomy in the early $21^{\text {st }}$ century

As we continue to understand the historical moments that led to contemporary agriculture, we cannot ignore Darwin, who worked with earthworms and developed the theory of evolution; Pasteur, who studied the process of soil nitrification and the microorganisms involved in that process, including nitrosomonas and nitrobacteria; Mendel, who determined the genetic basis of heredity by working with peas; Liebig, who contributed to the development of the law of the minimum as a restricting factor for productivity and soil fertility; Boussignault, who developed empiricism en el campo; Sprengler, who developed nutrient restitution; and Weber and Clements, who studied directional changes in the vegetation and soil, establishing the systemogenic basis of ecosystem evolution, which led to a major organization and, finally, to a climax (Maroto, 1998).

Regardless of the enormous technical advances in contemporary agriculture in late $20^{\text {th }}$ century, a unifying theory integrating the aforementioned aspects of agriculture was absent. Thus, a theoretical framework for localizing and framing agronomic engineering into an integrated, complex, holistic and transdisciplinary context was necessary, given the advances in scientific paradigms and engineering in the early $21^{\text {st }}$ century (Briggs and Peat, 1994; Röling, 2000; Wu and David, 2002; Jentoft, 2007). This theoretical framework emerged for agronomy and other disciplines, including general systems theory and ecology, where Smuts (1926), Tansley (1935), Odum (1953), von Bertalanffy (1968) and Margalef (1968) are notable contributors. These disciplines integrate complexity theory, cognition and panarchy (web of life) (Bohm and Peat, 1987; Capra, 1996; Naveh, 2000; Chiras et al., 2002; Gusderson and Holling, 2002).

New and more complex challenges must now be assumed. Science and engineering in the service of humanity are necessary to provide a better understanding of ourselves and our living environment (Costanza et al, 1997; Vitousek et al., 1997; Lubchenco, 1998; Maturana and Mpodozis, 2000; Plutchik, 2001). Therefore, a worthwhile question emerges: what are the challenges for contemporary agronomy as a science and profession if it focuses on resolving the problems for agriculture and rurality? The present article intends to determine how a systemic and ecological context begins as the backbone of agronomic engineering. The problems related to agriculture and agronomy are generally local, due to their immediacy; in the context of Cartesian control, researchers analyze isolated variables. These properties are observed with the chemical control of plagues, the development of improved varieties and the maintenance of soil fertility through chemical methods. However, there are higher-level topics in agronomy, such as ecology as a basic and applied science and its insertion into the science of agronomy. This discipline presents one possibility for solving problems in rural engineering (referred to as the application of engineering in rurality) with a paradigm based in ecology (Kuhn, 1971; Margalef, 1974, Gastó et al., 2009). These facts strongly contribute to the 
development of the philosophical, theoretical and heuristic strength of contemporary agronomy.

\section{Ecology in agriculture}

The term "ecology" comes from the word oikos, meaning house, and logos, meaning study (Gastó, 1980). Our house is our fatherhood in the sense of homeland, neighborhood, town, city, country, payment or any other manifestation of cultural landscape where we are positioned and structurally coupled (Maturana and Varela, 1972, 1992). Ecology is the study of home, and the ecosystem is the organization of that home. There is a third concept, "economy," that cannot exist without the other two concepts; in this context, economy refers to the administration of home. In the past, the term "economy" referred to the supply of elements and goods for the development of human life, which corresponds to our current meaning for the term "ecology." What contemporary society terms "economy" is the old "chrematistics," which was the art of administration and earning money (Martínez, 1987; Subercaseaux, 2007).

Current agriculture is the result of an evolutionary process, beginning with humans as hunters and collectors, when they begin to coevolve with their environment until they create a socially structured society as an ethnic community that is coupled to the rural environment that they inhabit (ethnos) (Berdichewsky, 2002). This development allows humanity to begin the process of nature domestication and transforming their home into a controlled environment with a wide state of ruralization. Nature was partially transforming into country in this state, as it was originally occupied by unaltered wild areas (silva) (Vera and Gastó, 2011). Urbanization, the next stage, is the process that led to the development of permanent human settlements that were complemented with the typical constructions (polis) but that still contained a rural world and a world that remained wild in the periphery (Gastó and Vera, 2009). Next, the farming stage began, in which property activi- ties were organized to artificialize nature and, subsequently, to generate a consumption surplus for the support of industry and cities. Property activities were carried out in estates, country estates, ranches, plots and noble houses and have been sufficiently successful that a gradual increase in urbanization to create towns, villas, villages, cities and metropolises has been made possible. A constant reduction in the rural population has occurred simultaneously with the intensification and globalization of farming. In the final stages, after intensive urbanization, the current need for nature inclusion emerges again, integrating nature with culture and society (Ohrens et al., 2007). At present, greater biophilia and topophilia needs have strongly emerged in society; these needs are expressed by current trends, including the agriculture core (Tuan, 1979; Wilson, 1984; Baird, 1988; Lubchenco, 1998). These trends derive from the integration of the three fundamental elements of nature, culture and welfare, which integrate dynamically as panarchy (Gunderson and Holling, 2002; Naredo, 2004, Gastó et al., 2006).

Substantial changes have occurred in the last 10,000 years, when cultivation and husbandry were invented. Re-rústica was mentioned in the early Christian era, in times of Columela (Columela, 1959, original book from the first century A.D.), which corresponds to rurality existing with urbanity (polis) in small, well-structured cities and towns in the territories of Babylon, Greece and Rome (Hughes, 1975; Ponting, 1992). It was necessary to supply cities with abundant food; therefore, efficient, specialized pieces of land, such as ranches and farms, were required to produce this food. The English term "farming" derives from this specialization, which is different from cropping and husbandry. Farming could be defined as the arrangement, management and administration of rural pieces of land, the activities of which are focused on the land coordinated with technological activities related to the sensu lato agriculture (Gastó, 1980; Gastó et al., 2009). For example, in the case of salmon, there is aquaculture or cultivation in Chile; salmon farming 
in English means the development of salmon country properties with all of the implications of the territorial localization of activities and governance of the cultural landscape (Vargas, 2005; Gastó et al., 2006; Vera and Gastó, 2011).

Similarly, we could discuss a milk, cereal, fruit or forest country property and not focus only those related to cattle or cultivation. The main problem is the transition from a paradigm focused on plants or animals to a paradigm focused on social stakeholders and the organization, management and administration of the land for rural purposes. In this new paradigm, life is linked to the country, surplus production to provide for industry and cities and the protection of complementary wild ecosystems.

The concepts and terms that are used in daily language appear as long as society requires them; these terms eventually become obsolete and extinct when they have lost their meaning. This loss of meaning is the case for "re-rústica" in the Roman time of Columela in the early Christian era. Barnhart (2004) indicates in his etymological dictionary that the term appeared in 1440 to describe the activity of cultivating and organizing country production. Subsequently, the word "culture" was derived from this word. Thomas More introduced re-rústica to the language in 1510. Agronomy as a science and profession focused on the study and resolution of the problems of rural estates and, according to Maroto (1998), appeared in 1810 and 1818 in the universities of Moglin and Hochenheim (Germany). Agronomy later entered the universities of Georgikan (Hungary) and many universities in France, including Roville (1922), Nancy (1824) and Grignon (1926). Subsequently, schools of agronomy spread across Europe from the mid-19 ${ }^{\text {th }}$ century. The first school in Chile was created in 1867. The areas of specialization of these first schools included phytotechnics, zootechnics and engineering. Other concepts later evolved and were incorporated into the context of agronomy sciences.

According to Barnhart (2004), the concept of natural resources appeared in 1870 at the peak of the Industrial Revolution. This appearance can be explained by the need for raw materials from agricultural and wild areas, which began to be limited for industries and cities. Tröll (1939) and Forman and Godron (1986) developed, formalized and explained the concept of landscape ecology. This development represented a substantial change in the evolution of contemporary agronomic science, and it was followed by the development of the concepts of topophilia (Tuan, 1979) and biophilia (Wilson, 1984). Finally, the previous concepts were integrated and evolved to the concept of panarchy according to Gunderson and Holling (2002). The coevolution of agronomy and society has existed according to the spirit of the age (zeitgeist) and membership in the place (volksgeist) in accordance with Herder and generalized by Hagel (Maturana and Varela, 1992; Berlín, 1996; Ferrater-Mora, 1999; Gastó et al., 2009). This coevolution has led to the incorporation of ecology as a fundamental integrator of contemporary agronomy, where nature, culture and societal well-being converge, transforming agronomy from an analytical, Cartesian science to a systemic (Tansley, 1935; von Bertalanffy, 1968, Naveh, 2000; Naveh and Liberman, 1984; Savory, 1988, Nava et al., 1996), holistic (Smuts, 1926; Capra, 1996) and transdisciplinary science (Max-Neef, 2005).

Ecology involves agriculture (sensu lato) in different ways according to what we understand by ecology and the nature of the problem. Agriculture may be defined as "an economic activity focused on the production of cultivations sustainably and their transformation to forms consumed by man. Agriculture is made by many people as an activity for living" (Acevedo, 2009). This definition follows the approach of guidelines from farmer associations and the Ministry of Agriculture of Chile, who do not understand that agriculture is more than business, where environmental conditions frequently hinder development as a profitable commercial activity. According to Lawes (1847) and Prado (1983), agriculture may be defined as "the process of nature artificialization for human purposes." In this context, agriculture is not simply 
cultivation, but the existing nature in a section of land undergoes a transformation to create grassland, cultivation, husbandry or plantations (Gastó et al., 2002). Agriculture and rurality depend on nature, as expressed by the ecosystem services of the land. Agriculture is responsible for 2 out of 17 ecosystem services described by Contanza et al. (1997): food production and raw materials. The other services are rurality services. In the 1970s, agriculture was defined as "putting a harness to solar energy by plants, with human purposes" (De Wit, 1974, cited by Röling, 2000) when hard productivist technologies were imposed. A previous definition from 1814 defined agriculture as the "science of managing farmland" (Barnhart, 2004), which is solid and complementary and integrates the preceding definitions because it involves nature and artificialization with land management organized as rural pieces of land. The topic of ecology is essential in all of these definitions. In recent decades, however, agriculture has been defined and considered only as agribusiness, which diminishes its importance and meaning and creates only a minor economical branch (Martínez, 1987). This narrowed definition of agriculture occurred in Chile, especially during the second half of the $20^{\text {th }}$ century, and it continues to the present time. Agriculture has generally focused on cultivation in economy and enterprise, ignoring the land dimension and, in many cases, causing the degradation of the country's natural resources (Gastó, 1980; Altieri and Rojas, 1999; Vera and Gastó, 2011). In this context, hacienda was the most important territorial, social, economic and management activity in the first 300 years since the conquest and colonization of America, subsequently complementing the country state in all expressions (Rondón, 1994; Ohrens et al., 2007).

Ecology has been integrated formally and severely with the development of general system theory since the 1920s and with the ecosystem since 1935 (Tansley, 1935). This integration was generalized in the 1960s and 1970s. It is difficult to state that contemporary agronomy might be sustained and develop in a context lacking ecology as a fundamental paradigm because of the territorial agricultural matrix that was generated from the artificialization of the natural ecosystem to transform them into pieces of rural land and because of the expansion of the generalized agricultural frontier as a global phenomenon (Vitousek et al., 1997; Lubchenco, 1998; Röling, 2000; Huston, 2005; Vera and Gastó, 2011).

Agronomy cannot exist without agriculture because the presence of the first solves the problems of the second. Similarly, we might say that medicine is a science and profession with the main objective of solving health problems. It should be noted that although business is important in medicine, it has always been maintained that health and not business is the central focus (Kent, 2010). In the case of agronomy, the focus has been distorted in recent decades. Business has been highlighted as the fundamental objective, and the localization was confusing. Therefore, agronomy schools in Chile have abruptly become agribusiness schools, although they apparently do not resemble traditional agribusiness schools. There is important agricultural business that is derived from the use of the land. However, the process should not be distorted until complementary damages are generated to the global system, to the urban complements and to the complementary protected wild areas.

\section{Ecology in agronomy}

Careers related to agricultural activities were created near the height of the Industrial Revolution. At that time, industry began to require larger amounts of raw materials from nature, which became progressively scarcer and were considered tradable goods. Agronomy science was born in this context in 1810 (agronomic engineering) as a profession destined to produce raw materials and cheap and abundant food for industrial workers and for urban centers that were beginning to experience great development. This development similarly occurred for forest activities (forest en- 
gineering), developing professions for the growth, production and development of wood technology, which was required for shipping construction and for other complementary activities of industry and housing. Likewise, veterinary medicine emerged in 1765 and was focused on cattle development and animal health for both military activities and for satisfying the increased food demand. All of these professions were born and developed for productive purposes, justifying the focus of business and profits. However, their common base is ecology, the ecosystem, land management and the condition of the resulting cultural landscape.

The structure of agronomy as a science and profession may be presented in four disciplinary levels of integration focused on the ecological theory and ecosystem (Figure 1). The first level refers to the inorganic empirical sciences such as chemistry, physics and geology and the organic empirical sciences, such as genetics, physiology, taxonomy and nutrition. These sciences are integrated as an ecotope and biocoenosis. Conversely, ecotope and biocoenosis represent the ecosystem generically, where such disciplines as horticulture, entomology, viticulture, sheep breeding, praticulture and silviculture represent their specific dimension. All of these disciplines are particular cases of applied ecology with a strong technological base of nature artificialization. The third level of integration incorporates society with artificialized nature, incorporating the components of the rural world, such as an environment for the development of life and inhabitance, which is complementary to urban and protected wild aspects. These levels are the context of contemporary transdisciplinary agronomy. The fourth level integrates agronomy as a science with the profession of agronomy engineer (the science or discipline that focuses on solving the problems of agriculture), where normative and evaluative elements are incorporated.

\section{Modern transdisciplinary paradigm of agronomy}

Agronomic phenomena may be analyzed and presented from five different perspectives or

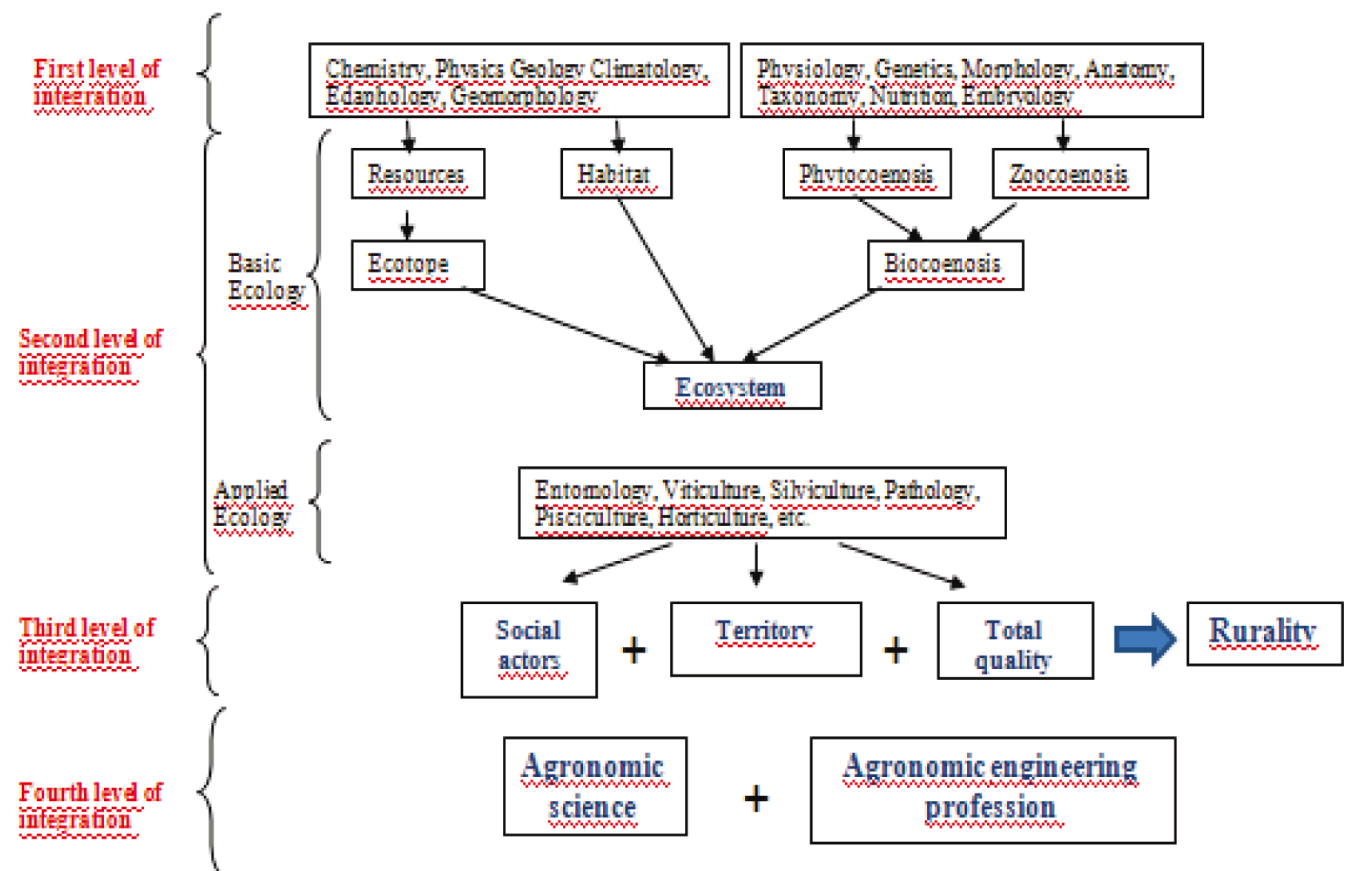

Figure 1. Scheme of the structure of integration levels of agronomic science as the basis of rural engineering focused on solving the problems of agriculture and rurality (Modified from Gastó, 1980). 
dimensions, which represent a long epistemological and etymological process that currently allows agriculture to be analyzed rigorously and systematically in the context of the modern scientific disciplines related to nature artificialization. The first dimension represents the phenomenological base: nature expressed as a territorial matrix (Forman, 1995). In this context, a second dimension is the land, which may be defined as a portion of land or aquatic surface that belongs to a piece of land, region or country that is occupied by social stakeholders, where mutual relationships of structural coupling occur (Maturana and Varela, 1992; Gastó et al., 2002). Nature, conversely, is the cluster of all of the entities and forces composing the land, the natural world without man and civilization. Nature represents the background matrix where the human species has evolved, leading to rurality and urbanity as complements to wild areas (Gastó, 1980; Pontig, 1992). The third dimension corresponds to natural resources. These resources are the supply source of our civilization, and they support life based on a natural matrix (Maturana and Varela 1992; Röling, 2000). Therefore, those resources must be maintained sustainably. Agronomic activities mainly order, manage and administer those resources. Ecosystem is the fourth dimension and one of the most recently developed concepts. This concept allows the localization and integration of different disciplines to place agronomy in a transdisciplinary dialogue. Finally, the concept of cultural landscape strongly emerges as a fifth dimension, which may be defined as "what is left after acting on land" (De Bolos, 1992; Vargas, 2005 Gastó et al., 2006); this dimension represents the environment that results from the aforementioned activities. This dimension is the space where agriculture and rurality develop in a coevolutionary process between society and nature that is explained etymologically by the chronological evolution represented by the coining dates of different terms (Maturana and Varela, 1992; Barnhart 2004; Ohrens et al., 2007).
In general, similar to other complex professions, such as medicine, architecture and engineering, the components of agronomic science extend from a single discipline to interdisciplinary work (Gastó, 1980; Max-Neff, 2005). Due to this science's transdisciplinary nature, science and agronomic engineering exist in a context with different disciplines and hierarchical levels. As shown in Figure 2, the first level (superior) is the evaluative level. In general, ethical, aesthetic and philosophical elements are localized to these levels. These levels show the first degrees of freedom of the system. The normative level is under this level. The elements of politics, planning, design and, in general, the normative arrangement of lower levels emerge in this level. The third level is pragmatic, centered in the approach and problem resolution and the practice of different trades and professions. The fourth and last level is empirical, where the empirical fundamentals allow the ordered comprehension of the world. In this context, agronomy development is centered in the fourth level, i.e., empiricism; however, professions tend to focus on the third level, i.e., pragmatism. This distinction the case for architecture, civil engineering, forest engineering and medicine. Public policies and professionals are particularly focused on the normative and pragmatic levels (Gastó et al., 2002; Max-Neef, 2005).

Ecology represents the basic science needed for the study and development of the conservation and management of renewable natural resources. Ecology is the discipline that unifies and integrates different environments, composing agronomy as a science and agronomic engineering as a profession. Nature, the fundamental concept for ecology, may be defined as the clustering, ordering and arrangement of all entities and forces composing the universe. Nature is the natural world without man or civilization (Ferrater-Mora, 1999; RAE, 2001). The natural world represents the background matrix where the human species has evolved over time (Roselló, 2010). 


\section{Hierarchical Levels of Transdisciplinarity Integration}

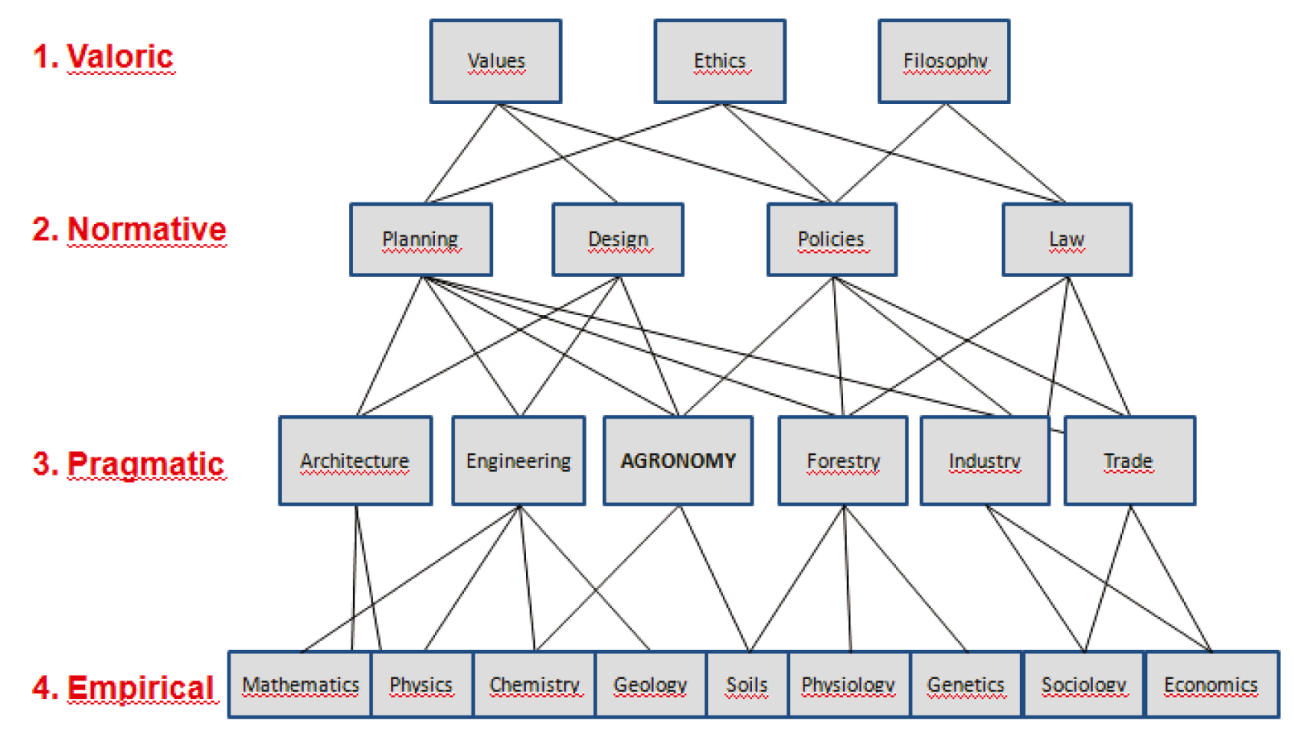

Figure 2. Transdisciplinary insertion of the profession and science of agronomy in the four hierarchical levels of integration, according to Max-Neff (2005).

The definition of nature as a wild area and the descriptive and resolute approach necessarily require localization from a philosophical and ecological perspective; a transition to renewable natural resources from these stages is impossible without that perspective (Gastó, 1980; Röling, 2000; Doherty and Rydberg, 2002). In the first stage, nature focuses on utilitarianism because it is a pragmatic level that includes society culture, defined as how to integrate the world. The following stages introduce a legal dimension of the appropriation of natural goods organized in the land for management because it is a scientific and professional context that is focused on land. Next, the evaluative aspect is introduced, which is focused according to transactions that may be economical or of a different nature. Finally, a management dimension is introduced to develop a context of the production and renovation of the natural resource. As a background matrix, the transition from nature to a renewable natural resource is complex, with both ends being conceptually different. The cultural, legal, economic management, conservation and sustainability dimensions are incorporated, reinforcing the fact that they are different. The ecological theory is the central backbone of this transition as a theoretical transdisciplinary base.

During the $20^{\text {th }}$ century, the traditional paradigm of "action science" and the agronomic profession focused on three fundamental components: sectors, people and efficiency. Under this paradigm, results are defined by success or failure (Figure 3a). The sectors refer to the actions that are carried out by people and their economic needs as a result of the pragmatic level. That evaluation is mainly economic. The results are evaluated as success or failure based on the calculation of economic indicators, such as IRR (Internal Rate of Return) and NPV (Net Present Value). The new paradigm of $21^{\text {st }}$ century is focused on the territory instead of the sectorial area; on social stakeholders instead of people and on global quality instead of efficiency (Figure 3b). The global indicator of the resultant paradigm depends on the functional determinants of an ecological, social and economic nature, which is obtained by 
determining the space of the solution according to the model proposed by Nijkamp (1990). This model indicates that economic productivity, social equity and ecological sustainability are exhaustive variables and are mutually exclusive; their balance depends on the conditions of the territorial environment.

\section{Ecology as an integrative science for nature artificialization}

In countries such as Chile, where the land has undergone an intense and abrupt transformation from its original state, which was represented by ecosystems, such as forest and natural prairies, land clearing has been the most transcendent event in the transformation into a cultural landscape (Gay, 1885; Peri, 1989; Altieri and Rojas, 1999; Verniory, 2001; Vera and Gastó, 2011). However, a portion of this land, covered by native forests, natural prairies, glaciers, rock sites, beaches, lakes and

\section{A) CONVENTIONAL PARADIGM CENTURY XX}

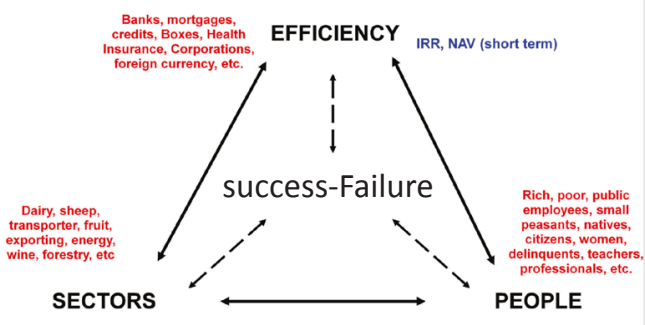

B) NEW PARADIGM CENTURY XXI

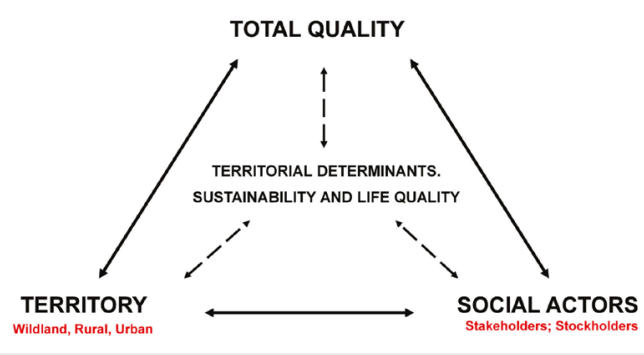

Figure 3. Traditional paradigm (a) and new paradigm (b) related to the localization of the science and profession of agronomic engineering, according to Gastó and Vera (2009). rivers, remain as saltus (land without anthropic intervention); this is, these sections of land are not part of this transformative opening process (Gastó et al., 2010; Roselló, 2010). Another portion of land has been opened or cleared in the process of frontier expansion, becoming ager (farmed land) after the simultaneous extraction of some of the original components and their exploitation. Finally, there are inclusion sites, where both introduction and component intrusion have occurred, with predominant constructions. These sites represent polis (built land). Therefore, the land gradually becomes a country (Ramos, 1987) in a cultural landscape composed by these three components: saltus, ager and polis. In 1595, the concept of country emerged from the integration of these components. These components are organized and complemented in different proportions composing the wild, rural and urban territories (Figure 4).

The fundamental matters that need to be incorporated for the development of ecology as a basic integrative discipline of science and the agronomic profession are the same for the development of other branches of ecology (Gastó, 1980; Röling, 2000; Wu and David, 2002). Therefore, agronomy may be defined as the profession intended to resolve agricultural problems. The context of these problems is the artificialization

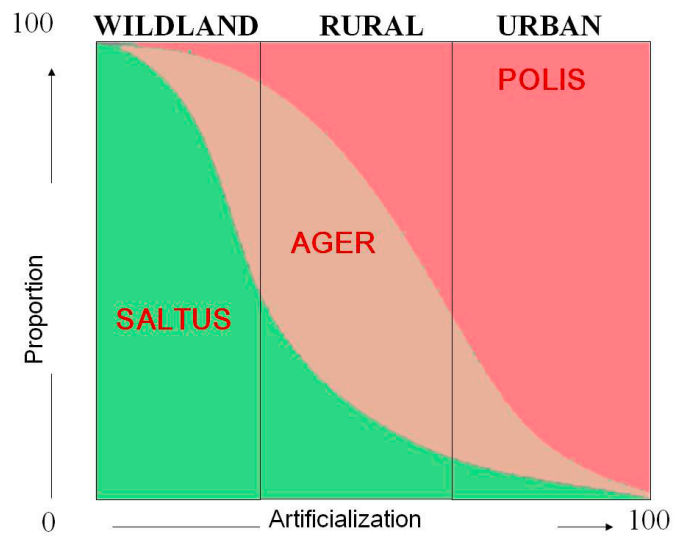

Figure 4. Proportional territorial integration of the categories essential to the cultural landscape (saltus, ager and polis) in the classes of territorial management and administration (wild, rural and urban) based on the degree of environmental artificialization (modified from Gastó et al., 2010). 
of nature for human purposes, where decisions are focused on rurality development. The development of agronomy must be presented within the perspective of ecological history and its environment as a first stage of development of the ecological aspect because, in general, agronomy is a discipline resulting from a long evolutionary process. The development of empirical sciences was previously necessary; after their development, pragmatic, normative and evaluative aspects were introduced.

The center and origin must be established in the second stage to develop the language related to the matter, which corresponds to general system theory and the evolution of holism. This development is mainly localized in the ecosystem and ecosystemorigin (Nava, et al., 1996; Gastó et al., 2002). Thus, the principles and regulatory mechanisms of artificialized nature are established. The failures and dysfunctions of the system are localized in the clinical methodology of natural and artificialized ecosystems; by their testing, diagnosis and treatment, they are considered fundamental patients of the profession (Ledley and Lusted, 1959; Kottow, 1980; Baird, 1988; Schaeffer, 1996; Lehman, 2000).

The ecosystem architecture must be presented and analyzed in the third stage, which corresponds to the systematic and rigorous study of its anatomy and morphology, upon which its behavior depends. Basins must be the central component as the geomorphological structure of the natural and artificial organization of the hydrosphere, geosphere and atmosphere along with phytocenosis and zoocenosis. The anthropocentric and ecocentric dimensions are incorporated in this stage, including the local and global dimensions of the phenomenon. Matters related to the progression and retrogradation of biocenosis and the ecotope must be emphasized in this stage (Gastó et al., 2009).

The fourth stage corresponds to the approach and analysis of the behavior and function of the ecosystem. The behavior of the artificialized system depends on the architecture conditioned by the topological arrangement of the components and their number and size, due to the structure of the hydrological, atmospheric, geomorphological and biocenosis background matrix (Gastó, 1980; Gastó et al., 2002). In this context, both nature and the ecosystem represent a dynamic structure caused by two forces. The endogenous process depends on the ecological succession (systemogenesis) from four essential components: phytocenosis, zoocenosis, climatope and edafotope are mutually integrated and modified until they reach states of higher balance in the major maturity or climax stages. The process may be directional and relatively predictable and shows the ecosystemic change. Conversely, artificialization is the product of endogenous changes in nature along with exogenous operators of artificialization (Margalef, 1963; 1974; Prado, 1983; Margalef, 1993).

The rural cultural stage occurs in the last stage of ecosystem development with high or low degrees of artificialization involving the combination of saltus, ager and polis, which are arranged and organized for territorial management and administration in wild, rural and urban zones. This arrangement allows governance or controllability to the land that is harmonious with cultural spaces (Costanza et al., 1997; Jentoft, 2007). The reference environment depends on nature and culture as scenery for the development of human well-being (Reed and Rothemberg, 1993).

In general, ecology is an integrated science for nature artificialization, and transformation into ager is the theoretical basis that allows the establishment of the transdisciplinary center of agronomic science and the professions of agronomic engineering and rural engineering. Ecology establishes the basis for development and evolution without which the generation of a rigorous, systematic and formal development in the current context of science and profession is not feasible. We are not living a time of change but rather a change of time that requires a gradual solution of the problems generated through a long process by the ager transformation by the path of ecology (solvitur ambulando) (Gell-Mann, 1995). 


\title{
Resumen
}

\begin{abstract}
J. Gastó, D. Subercaseaux y L. Vera. 2012. Ecología: ciencia integradora para la artificialización de la naturaleza. Cien. Inv. Agr. 39(3): 397-410. Se abordan los desafíos centrales de la agronomía contemporánea, en función de las emergentes y complejas problemáticas de nuestra época. La agronomía corresponde a la ciencia y profesión focalizada en resolver los problemas de la agricultura. Se muestra el surgimiento de la agronomía inserta en procesos socioculturales y su coevolución con ellos, resultando aquello determinante para la artificialización de la naturaleza, el manejo de los recursos naturales y la transformación del territorio. Desde la integración de naturaleza, cultura y bienestar emergen las tendencias que se expresan en el paisaje cultural. La ecología, el ecosistema, el territorio y el paisaje cultural como resultante emergente, otorgan las bases para abordar integralmente el estudio y desarrollo del manejo de los recursos naturales y de los ecosistemas, lo que permite además comprender la transición desde naturaleza a recurso natural. Todo esto se asocia a la transición de la agronomía desde una ciencia analítica de naturaleza cartesiana a una sistémica de naturaleza integradora, conducente a un paradigma holístico y transdisciplinario, lo cual debe ser aplicado a la profesión agronómica y a la ingeniería rural. El paradigma moderno de la agronomía para su operatividad ante las problemáticas constituyentes de nuestra época, ha de ser holístico, transdisciplinario y transversal a los cuatro niveles jerárquicos de las ciencias, además de adaptativo a las particularidades de los diferentes lugares y al devenir de los procesos propios de los sistemas complejos asociados a la construcción de una ruralidad sustentable y propicia para la calidad de vida.
\end{abstract}

Palabras clave: Agronomía, ecosistema, territorio, evolución de la agronomía, paisaje cultural, procesos socioculturales, recursos naturales, transdisciplinariedad.

\section{References}

Acevedo, E. 2009. Fisiología de cultivos: intensificación sustentable, captura de carbono y aumento del rendimiento potencial y rendimiento bajo estrés en los grandes cultivos. Laboratorio de relación suelo-agua-planta, Universidad de Chile, Santiago, Chile. http://www.sap.uchile.cl/ descargas/fisiogenetica/Desafios_cientificos.pdf (Website accessed: April 11, 2011).

Altieri, M. and A. Rojas. 1999. Ecological Impacts of Chile's neoliberal policies, with special emphasis on agroecosystems. Environmental, Development and Sustainability 1:55-72.

Baird, J. 1988. Agroecology in context. Journal of Agricultural Ethics. 1:3-9.

Barnhart, R. 2004. Chambers. Dictionary of etimology. H.W.Wilson Company. New York, USA. 582 pp.

Berdichewsky, B. 2002. Antropología Social: Introducción. Una visión Global de la Humanidad. LOM Ediciones. Santiago, Chile.
Bohm, D. and D.F. Peat. 1987. Science, Order and Creativity. A Dramatic Look al the Roots of Science and Life. Bantam Books. New York, USA.

Briggs, J. and D.F. Peat. 1994. Espejo y Reflejo: del Caos al Orden. Guía ilustrada de la teoría del caos y la ciencia de la totalidad ( $2^{\mathrm{a}}$ ed.). Barcelona, España. Editorial Gedisa (Traducción del original en inglés Turbulent mirror. NY: Harper \& Row, 1989].

Capra, F. 1996. The Web of Life. A New Synthesis of Mind and Matter. Harper Collins Publishers. Londres, Reino Unido.

Columela, M. 1959. (Libro original del siglo I d.C.). Los 12 Libros de la Agricultura. Editorial Iberia SA. Barcelona, España.

Costanza, R., R. D’Arge, R. De Groot, S. Farber, M. Grasso, B. Hannon, K. Limburg, S. Naeem, R. O’Neil, J. Paruelo, R. Raskin, P. Sutton and M. Van Den Belt. 1997. The value of the world's ecosystem services and natural capital. Nature Magazine 387: 253-260. 
Chiras D., J. Reganold and O. Owen. 2002. Natural Resource Conservation. Prentice Hall. New Jersey. USA.

De Bolos, M. 1992. Manual de Ciencia del Paisaje. Teoría, Métodos y Aplicaciones. Editorial Masson. Barcelona, España.

Doherty, S. and T. Rydberg. 2002 (eds.). Ecosystem properties and principles of living systems as foundation for sustainable agriculture. Ecological Agriculture $\mathrm{N}^{\circ}$ 32. Center for Sustainable Agriculture. Swedish University of Agricultural Sciences. Uppsala, Sweden.

Ferrater, J. 1999. Diccionario de Filosofía. Ariel. Barcelona, España. 2747 pp.

Forman, R. 1995. Land Mosaics. The Ecology the Landscapes and Regions. Cambridge University Press. Cambridge, UK. 632 pp.

Forman, R. and M. Godron. 1986. Landscape ecology. John Wiley. New York. USA. 619 pp.

Gastó, J. 1980. Ecología. El Hombre y la transformación de la naturaleza. Editorial Universitaria. Santiago, Chile. 573 pp.

Gastó, J., P. Rodrigo and I. Aranguiz. 2002. Ordenación Territorial. Desarrollo de Predios y Comunas Rurales. Pontificia Universidad Católica de Chile. LOM Editores. Santiago, Chile. 995 pp.

Gastó, J., L. Vieli and L. Vera. 2006. Paisaje Cultural. De la Silva al Ager. Agronomía y Forestal UC 28: 29-33.

Gastó, J. and L. Vera. 2009. Ordenamiento y sustentabilidad territorial en un mundo centralista. In: Von Baer, H. (ed.). Pensando Chile desde sus regiones. Ediciones Universidad de la Frontera. Temuco, Chile. p. 455-473.

Gastó, J., L. Vera, L. Vieli and R. Montalba. 2009. Sustainable agriculture: Unifying concepts. Cien. Inv. Agr. 36: 5-26.

Gastó, J., M. Gálvez and P. Morales. 2010. Construcción y articulación del paisaje rural. Changing landscapes: perception, natural disturbance and the reconstruction of landscapes. AUS (Valdivia) 7: 6-11.

Gay, C. 1885. Historia Física y Política de Chile. Agricultura. Reedición: ICIRA (Instituto de Capacitación e Investigación en Reforma Agraria) 1973. Volumen I y II. Proyecto Gobierno de Chile-FAO.
Talleres gráficos de ICIRA. Santiago, Chile. 487 pp.

Gell-Mann, M. 1995. El quark y el jaguar. Aventuras en lo simple y en lo complejo. Tusquets Editores S.A. Barcelona. 413 pp.

Gunderson, L. and C. Holling (eds.) 2002. Panarchy. Understanding Transformations in Human and Natural Systems. Island Press. Washington, USA. 507 pp.

Jentoft, S. 2007. Limits of governability: Institutional implications for fisheries and coastal governance. Marine Policy 31: 360-370.

Hughes, J. 1975. Ecology in ancient civilizations. University of New Mexico Press. Alburquerque. N. M. 181 pp.

Huston, M. 2005. The three phases of land-use change: implications for biodiversity. Ecological Applications 15:1864-1878.

Kent, D. 2010. Just-as-good medicine. American Scientist 98:102-105.

Kottow, M. 1980. Defining Health. Medical Hypotheses 6:1097-1104.

Kuhn, T. 1971. La estructura de las revoluciones científicas. Fondo de Cultura Económica. México D.F., México. 319 pp.

Lawes, J. 1847. On agricultural chemistry. J. Royal Agric. Soc. England. 8:226-260.

Ledley, R. and L. Lusted. 1959. Reasoning Foundations of Medial Diagnosis. Science 130:9-21.

Lehman, H. 2000. Ecosystem Health as a Moral Requirement. Journal of Agricultural and Environmental Ethics 12:305-317.

Lubchenco, J. 1998. Entering the Century of the Environment: A New Social Contract for Science. Science 279:491-496.

Margalef, R. 1963. On certain unifying principles in ecology. Am. Naturalist 97:357-374.

Margalef, R. 1968. Perspectives in ecological theory. University of Chicago Press. Chicago, USA. 111 pp.

Margalef, R. 1974. Ecología. Editorial Omega. Barcelona, España. 951 pp.

Margalef, R. 1993. Teoría de sistemas ecológicos. Publicacions Universitat de Barcelona. Barcelona, España. 290 pp. 
Maroto, J. 1998. Historia de la Agronomía. Una versión de la evolución histórica de las ciencias y técnicas agrarias. Mundi-Prensa. Madrid, España. $371 \mathrm{pp}$.

Maturana, H. and J. Mpodozis. 2000. The origin of species by means of natural drift. Revista Chilena de Historia Natural 73: 261-310.

Maturana, H. and F. Varela. 1972. De Máquinas y Seres Vivos. Una teoría de la organización biológica. Editorial Universitaria. Santiago, Chile. $137 \mathrm{pp}$.

Maturana, H. and F. Varela. 1992. The Tree of Knowledge, the Biological Roots of Human Understanding. Shambala Publications. Boston, USA. 269 pp.

Max-Neff, M. 2005. Foundations of transdisciplinarity. Ecological Economics 53:5-16.

Naredo, J. 2004. Diagnóstico sobre la sostenibilidad: La Especie Humana como Patología Terrestre. Archipiélago 62: 13-24.

Nava, R., R. Armijo and J. Gastó. 1996. Ecosistema. La unidad de la naturaleza y el hombre. Editorial Trillas. México. 332 pp.

Naveh, Z. and A. Lieberman. 1984. Landscape Ecology. Springer Verlag. New York, USA. 356 pp.

Naveh, Z. 2000. What is holistic landscape ecology? A conceptual introduction. Landscape and Urban Planning 57:269-284.

Nijkamp, P. 1990. Regional sustainable development and natural resource use. In: Proc. World Bank Annual Conference and Development Economics. Washington D.C., USA. 215 pp.

Odum, E. 1953. Fundamentals of ecology. W.B. Sandero. Filadelfia, USA. 546 pp.

Ohrens, O., J. Alcalde and J. Gastó. 2007. Orkestiké. Agronomía y Forestal UC 31: 22-25.

Peri, R. 1989. Reseña de la colonización en Chile. Editorial Andrés Bello. Santiago, Chile. 250 pp.

Plutchik, R. 2001. The Nature of Emotions. American Scientist 89:344-350.

Ponting, C. 1992. A green history of the world. Sinclar-Stevenson. Londres. 582 pp.

Prado, C. 1983. Artificialización de ecosistemas. Planteamiento teórico para su transformación y optimización. Tesis de Ing. Agrónomo. Universidad de Chile. Santiago, Chile. 233 pp.
Ramos, A. 1987. Diccionario de la naturaleza. Hombre, ecología y paisaje. Espasa-Calpe. Madrid, España. 1016 pp

Reed, P. and D. Rothemberg (eds.). 1993. Wisdom in the open air. Univ. Minnesota Press. Minneapolis, USA. 142 pp.

Röling, N. 2000. Gateway to the Global Garden: Beta/Gamma Science for Dealing with Ecological Rationality. Eight Annual Hopper Lecture. University of Guelph, Canada. 51 pp.

Roselló, S. 2010. Implementación de una metodología para la determinación del potencial de artificialización en ecosistemas de montaña. Tesis para optar al título de Ingeniero Forestal. Pontificia Universidad Católica de Chile. Santiago, Chile. 126 pp.

Savory, A. 1988. Holistic resource management. Island Press. Covelo, California. USA. 564 pp.

Schaeffer, D. 1996. Diagnosis ecosystem health. Ecotoxicology and Environmental Safety 34:18-34.

Smuts, J. 1926. Holism and evolution. Mac-Millan. New York, USA. 362 pp.

Subercaseaux, D. 2007. Paisaje Cultural: Implicancias ecológicas de la priorización del lucro económico. Bases teórico-conceptuales y planificación del paisaje cultural. Tesis Master of Science. Facultad de Agronomía e Ingeniería Forestal. Pontificia Universidad Católica de Chile. Santiago, Chile. 277 pp.

Tansley, A. 1935. The use and abuse of vegetational concepts and terms. Ecology 16:284-307.

Troll C. 1939. Luftbildplan and okologische bodenforschung. Zeitschraft der Gesellschaft fur Erdkunde Zu Berlin: 241-298.

Tuan, Ji - Fu. 1979. Space and place. Humanistic perspective. In: Gale, S. and G. Olson (eds.). Philosophy in geography. D. Reidel Publishing Company. Dorderecht, Holanda. p. 23-43.

Vargas, G. 2005. Naturaleza y medioambiente: una visión geográfica. Revista Geográfica Venezolana 46: 189-304.

Vera, L. and J. Gastó. 2011. Expansión de la Frontera Homínida en el Paisaje Cultural. Hominización, restauración y gobernanza de la Cordillera de Los Andes de la Araucanía. Editorial Académica Española. Saarbrücken, Alemania. 388 pp. 
Verniory, G. 2001. Diez años en Araucanía. Pehuén Editores. Santiago, Chile. 490 pp.

Vitousek, P., H. Mooney, J. Lubchenco and J. Melillo. 1997. Human Domination of Earth's Ecosystems. Science 277:494-499.

Von Bertalanffy, L. 1968. General System Theory:

Foundations, development, applications. George Braziller. New York. USA. 289 pp.
Wilson, W. 1984. Biophilia. Harvard University Press. Cambridge, USA. 157 pp.

Wu, J. and J. David. 2002. A spatially explicit hierarchical approach to modeling complex ecological systems: theory and applications. Ecological Modeling 153:7-26. 